\title{
Development of Public-Private Partnerships in The Agrarian Sector of Ukraine: Digitalization as a Priority
}

\author{
Nadiia Reznik, Anatolii Ostapchuk, Kateryna Alekseieva, Andrii Cherkasov, Igor L. Fedun
}

\begin{abstract}
The article substantiates the development of public-private partnerships in the agrarian sector of the economy of Ukraine stating the digitalization of it as a priority. In current conditions the agrarian sector is crucial for the economy of Ukraine that is proved by its economic figures. Simultaneously it bears a very important social role. Providing the beneficial interaction between the state and private business in the direction of digitalization of the agrarian sector through implementing public-private projects can become a significant step for raising both economic and social achievements in the sector and in the economy as whole. Thanks to the public-private partnerships in the agrarian sector the state can act as a partner carrying out control over food security, animals' health, social norms, logistics of the agrarian product, etc. without direct penetration into the sector. Implementing of this is possible through providing digital technologies in the sector which will allow providing modern schemes of the economic activity.
\end{abstract}

Key words: agrarian sector, cooperation between the state and business, digitalization, public-private partnerships.

\section{INTRODUCTION}

Nowadays in Ukraine as well as in other countries with market economy there is a situation to be accepted when agrarian producers are not able to solve many problems by themselves, for example to provide digital technologies into production mostly because of the need in significant financial costs and because of the fact that they are not ready to do that by themselves. It is worth saying that agrarian sector of Ukraine bears crucial role for the economy of Ukraine and this is proved by statistical and economic figures. It also plays an important social role providing social stability and reaching the food security, health, ecological and other goals of development. In this connection, there are prerequisites for cooperation between the government and small agrarian business and the spread of such a relatively new phenomenon

Revised Version Manuscript Received on October 15, 2019.

Nadiia Reznik, Head of the Department of Management of Organization named after Y. Zavadskiy, National University of Life and Environmental Sciences of Ukraine, Kyiv, Ukraine; nadya-reznik@ukr.net

Anatolii Ostapchuk, Dean of the Faculty of Agrarian Management, National University of Life and Environmental Sciences of Ukraine, Kyiv, Ukraine; aostpchuk@ukr.net

Kateryna Alekseieva, As. Professor of Production and Investment Management Department, National University of Life and Environmental Sciences of Ukraine, Kyiv, Ukraine; katerinaalex@ukr.net

Andrii Cherkasov, Head of the Department of Personnel Management and Labor Economics, Doctor of Economics, Professor, Institute of Personnel Training at the State of Employment Service of Ukraine, Kyiv, Ukraine; doc.cherkasov@gmail.com

Igor L. Fedun, Doctor of Economics, Associate Professor, Kyiv National University of Trade and Economics, Kyiv, Ukraine fil_2604@ukr.net, ORCID http://orcid.org/0000-0002-1012-9970, in the global economy as public-private partnership, in particular in providing the digital technologies into agrarian sector. Thanks to the public-private partnership in the developed countries of the world a lot of problems are solved, modernization and digitalization of production are being carried out, a competitive business climate is maintained, and the level and quality of life of people are increased.

It should be admitted that the effectiveness of public-private partnership largely depends on the fact whether the existing institutional relations in the country are favorable or not. The high level of corruption, bureaucratic retardation, legislative uncertainty and distrust of the authorities can be significant barriers to the development of partner relations between the Government and business. On the other hand, the existence of various associations of entrepreneurs who are really capable of lobbying their interests on legal grounds, well-thought-out legislation, competition, along with other positive factors, can significantly revitalize the development of public-private partnerships in particular in digitalization of agrarian sector.

\section{LITERATURE REVIEW}

Challenges of implementing public-private partnerships in the economy of Ukraine are now kept by the attention of scholars. In works of scientists different aspects of cooperation between the state and the business have been discussed. In works of Heyets, $V$ (2009) interaction of the development between the state, economy and society have been shown. Varnavskiy, V. (2005) pays attention to the problems of partnership between the state and the private sector, taking into consideration possible risks of such cooperation. Yushin, S. (2015) searches for the ways of development of the public and private partnerships in the agrarian sector of economy. Innovative ways of public support to production of concrete agrarian products (in particular oilseeds) are offered in the works of $N$. Reznik, $S$. Gupta, O. Sakovska, A. Ostapchuk, R. Levkina (2019).

Paying proper attention to the importance of the research of the Ukrainian scientists it is necessary to stress on the problem of creating public-private partnerships in the agrarian sector of Ukraine to stimulate its urgent digitalization as a priority of development. In this connection the topic of the current research can be considered relevant and deserves scientific discussion.

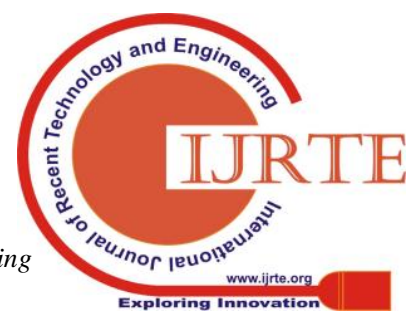


The main tasks of the article are substantiation of the importance of cooperation between the state and agrarian business in the direction of digitalization of it through providing public-private partnerships, outlining the importance of the agrarian sector for the economy of Ukraine and making it clear with the obstacles on the chosen way.

\section{METHODOLOGY}

To fulfill the stated tasks of the research a number of scientific methods have been used. The method of analysis and synthesis to analyze the role of the agrarian sector in the economy of Ukraine and work-out the main solutions to the problems in it through providing public-private partnerships oriented at digitalization of the sector. Using the method of logical conclusions allowed summing up the information and offering the SWOT-analysis of providing the public-private partnerships oriented at digitalization of the agrarian sector. Using the method of constructing schemes made it possible to present visual schemes of the research. There was also used statistical method to show some important figures indicating the importance of the agrarian sector for the economy of Ukraine.

\section{RESULTS}

Today agrarian producers especially the small ones are confronted with many problems, and they are faced with a new reality that requires providing digital technologies into production. That is why it is necessary to attract funds from different sources to meet the challenges of the current century and, accordingly, there are prerequisites for the development of cooperation between the state and municipalities, on the one hand, and business, on the other hand.

In Ukraine as in other post-socialist countries the processes of cooperation between the state and business have intensified, and most actively they take place in the real sector of the economy, agrarian sector, infrastructure branches (transport, housing and communal services), medicine, education, innovations. At the moment, even such strategic industry as for example the military-industrial complex is no longer exclusively state monopolies. It is worth saying that all mentioned branches and spheres of the Ukrainian economy are in need of urgent digitalization in order to overcome the gap with the developed countries of the world. Such problems can be solved through involvement of private (domestic and foreign) capital, which will allow enterprises to expand the resource base, mobilize unused resources for economic growth. In fact, there is a shift from the ideology of confronting state and business to partnering on a mutually beneficial basis, in particular in meeting the digital challenges of the current reality.

It should be noted that at present there is still no consensus among scholars on the essence of public-private partnership. For example, according to V.Varnavsky, public-private partnership is a form of indirect privatization [9, p.212]. This view is based on the study of the experience of countries with a developed market economy. In these countries, there has already been a redistribution of powers between the state and business with the transfer of the latter's broad powers relating to the possession, exploitation, construction and financing of objects of public interest. According to V.Geyets, public-private partnership is a form of optimizing the process of implementation and provision of public goods to the public. The state remains the owner of the resources and retains control functions in socially significant sectors of the economy, although it involves private capital and stimulates entrepreneurial initiative [3, p. 465].

Despite the differences in the interpretation of public-private partnerships, there is a number of common features in the understanding of such a partnership, i.e. the combination of state and business efforts, risk sharing, implementation of socially significant projects, and the use of state and municipal property [2, p. 61]. So under a public-private partnership one can understand any interaction between the state and private capital. Thanks to the public-private partnership creation of greater value added through providing digital technologies into economy can be provided that can lead to stimulating of economic development in the long run.

Agricultural production is the basis for food security of a country, which is determined by the following criteria: sufficiency of food consumption (the ratio of the actual level consumption of basic food products per person to medically recommended norms of healthy nutrition); availability of food consumption, a set of food products for one person, reasonable standards of healthy eating for one person and food independence, i.e. the share of food imports in total food consumption. Importance of agriculture to the Ukrainian economy becomes more visible in the context of foreign trade. Over 2010 - 2017, share of agricultural products in total export increased from $21 \%$ in 2010 to $44 \%$ in 2017 , while share of agricultural products in total imports fluctuated around $10 \%$. Agricultural exports have been the largest export category since 2013. In 2017, its share was almost twice larger than that of the second largest export category (ferrous and nonferrous metals). [1] Besides, agrarian sector plays a crucial social role. It is closely connected to human development and can be very often seen as a social lift for the young people born in the villages.

Despite all these facts which show the importance of the agrarian sector for the economy of Ukraine there have not been enough attempts to implement working public-private projects oriented at digitalization of agrarian sector of economy. In year 2017 there were 186 projects on the PPP basis officially implemented in Ukraine in such spheres as wastes utilization (112 projects, i.e. $60,5 \%$ of the total), water-use projects ( 37 projects $-20 \%$ of total), infrastructure projects (16 projects $-8,6 \%$ of total) and other projects. [4, p.19] It is worth saying that it is high time to start public-private projects in the agrarian sector of economy of Ukraine, especially the projects connected with digitalization of the sector. Public-private partnership model can be implemented to ensure the sustainable development of rural areas by concluding agreements between public and private partners in agricultural production and representatives of the social sector in villages. 
One of the biggest problems in agriculture that remains unsolved is connected to lack of development of infrastructure of agricultural market. The present market in its functioning does not allow free transparent movement of agricultural products and demonstrates lack of transparency in the scheme of implementation of the process of selling the agricultural goods and delivering them to the final consumers. This affects negatively the price situation in the agricultural market and does not give the producer opportunities to earn sufficient income from grown products. Among the factors that also affects of the process of sale of agricultural products in Ukraine is a small capacity of the primary agricultural market, i.e. lack of the direct supply of raw products to processing agrarian companies and simultaneously quantity of intermediaries growing from year

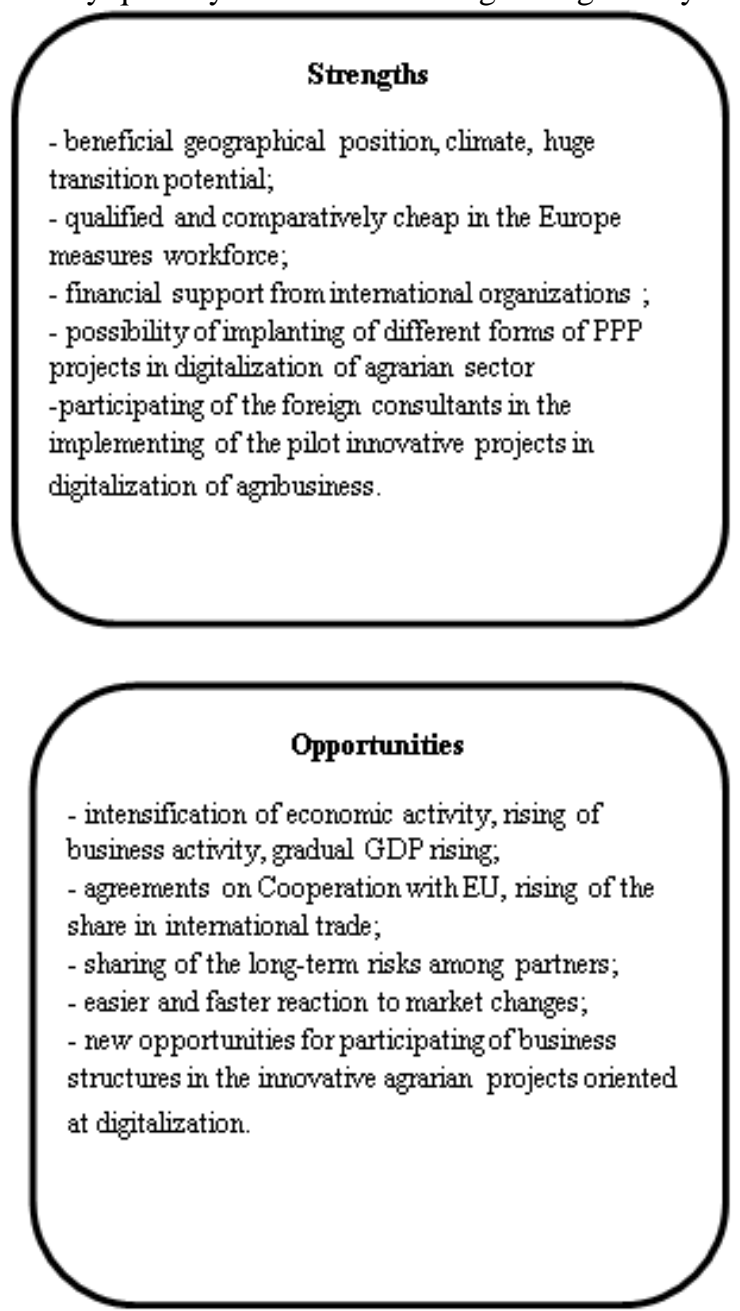

to year. With the help of development of public-private partnership in the agrarian sector it is possible to implement projects oriented at organizing precision agricultural schemes via digitalization of the logistic process of the agrarian products. As a matter of fact involving block chain technologies is one of the examples of raising the effectiveness of the process and lowering the risks. This means not only development of the existing markets of the existing products, but also getting rid of numerous intermediaries thanks to the direct agreements and raising effectiveness as a consequence. It also means creating new agricultural products and services production of which becomes possible thanks to implementing the digital technologies under the Government support.

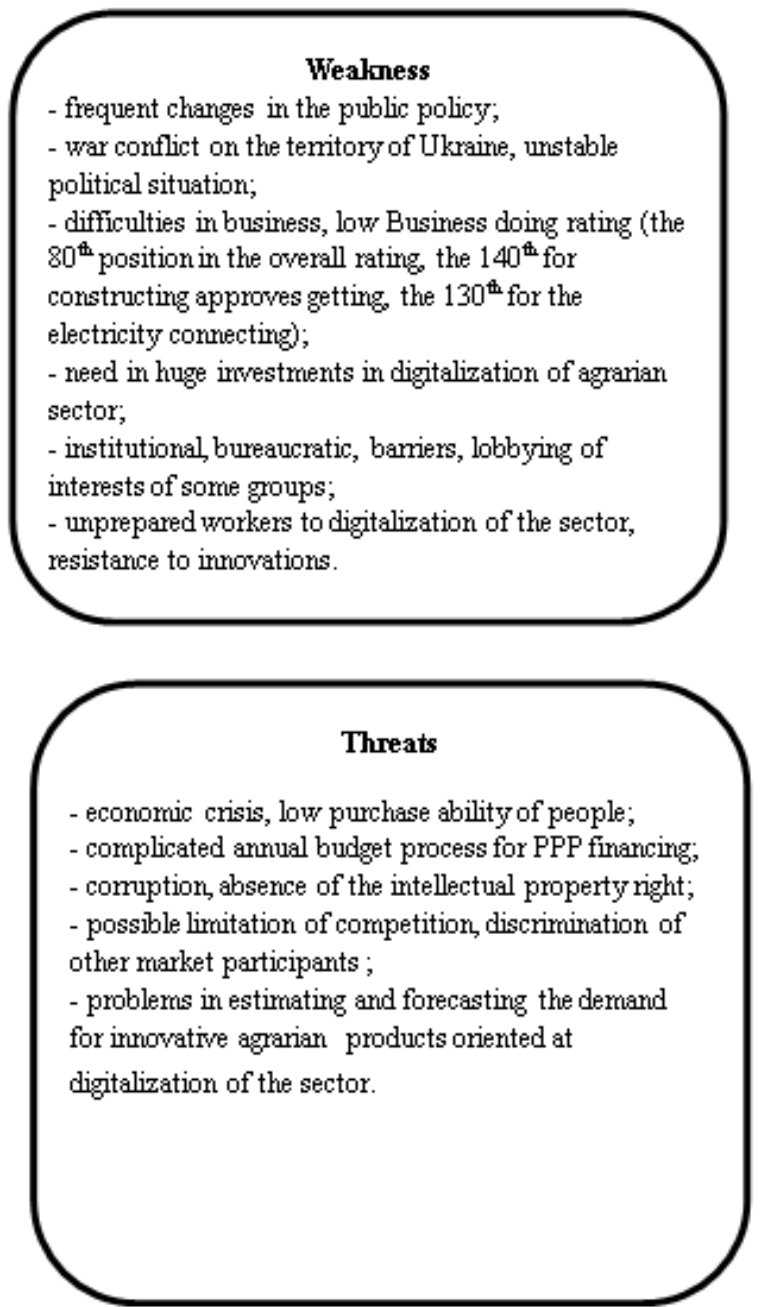

Fig. 1. SWOT-analysis of the perspective of the public-private partnership in digitalization of agrarian sector in Ukraine

*Source: made up on the basis of [4].

The SWOT-analysis of the perspective of the public-private partnership in digitalization of agrarian sector in Ukraine can provide us with general perception of its strategic necessity and possible backsides. (Fig. 1)

Agriculture provides meeting the public needs that requires proper Government attention in such directions as for instance food security, employment in the sector, health of the animals, climate and environment, water management and development of the villages. A lot of these public needs are not guaranteed by the market and require the government support. Thanks to digitalization of agriculture it turns

possible to provide interests such as food safety. Practical implementation of this is possible in particular through the projects based on the public-private partnership. Such projects can reduce negative external effects in a way that can become more attractive than by direct or indirect government regulation. Such projects allow developing competition at the agrarian market due to implementing of digital technologies into production, processing or logistic, create competitive

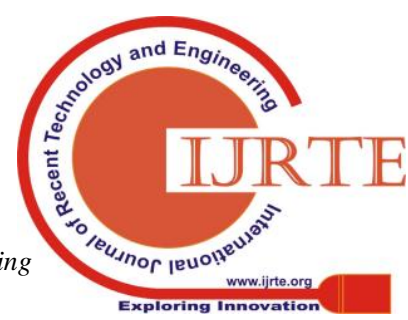


advantages to those who do this and stimulate the others (private entrepreneurs) to follow the example. For example it is crucial to control health of the animals in the livestock industry because it impacts the human health directly. Today, enterprises in the livestock industry independently introduce electronic systems that allow monitoring the state of animal health by creating electronic animal cards containing information about what they eat, what they are sick with, what drugs they treat, and the like. However, the development of this system cannot be complete without the help of the Government. After all, it is the Government that controls the quality of food products, which are, for example, in markets, in supermarkets. And digitalization is designed to automate and optimize these procedures, to make information more open and transparent. For providing quality control, it is necessary to implement public-private projects with comprehensive information from state regulatory authorities, veterinarians and manufacturers of veterinary drugs. The main task of the electronic system should be ensuring traceability in the production process - the entire history of the animal - on which farm it lived, which doctor treated it, whether antibiotics or other drugs were used, whether the treatment was effective, what the food was and the like. Thanks to such projects it is possible to organize day-to-day control and support over the production without direct intervention into the market.

In the Ukrainian practice the development of relations between the state and business, in particular in digitalization of agrarian sectors, is still complex and controversial. Unfortunately, instead of institutionalizing relations between them through the creation of diverse public associations, unions and associations often there is the penetration of certain business groups into political circles and lobbying their interests there in an illegal corrupt way. It can be frequently observed when the top of the consolidated business elite loses interest in establishing institutions for the promotion of public-private partnership having possessed the upper echelons of power. Since the consolidated business elite itself becomes a part of state or municipal government it starts to care about their own economic interests. Unfortunately there can be seen the formation and development of powerful oligarchic clans capable of initiating not only economic but also political shocks in the occasion of any possible threat to their monopoly influence on the legal government and non-government structures. All these factors bear negative impact on development of such progressive forms of doing business in all branches of the Ukrainian economy, in particular in digitalization of agrarian sector preventing from fast and innovative modernization of it.

In our mind it is necessary to admit that some really important steps have been done in direction of creation the institutional environment in implementing the public-private projects in Ukraine. First of all there have been several attempts in the first decade of the new century made in Ukraine to create organizations able to provide the mechanisms of PPP for a long time. In particular, the Ukrainian Union of Industrialists and Entrepreneurs, the Union of Entrepreneurs of Small and Medium-sized Privatized Enterprises of Ukraine operate. However, in Ukraine, such organizations, unfortunately, have not become really influential on economic, political, and managerial processes and could not really support and protect business representatives, since they did not have the authority of the representatives of the oligarchic circles. The next important step towards institutionalization of relations between the state and business was that in 2010 the Verkhovna Rada of Ukraine adopted the Law of Ukraine "On Public-Private Partnership" [5]. The Law defined the principles of equality of partners and the coordination of their interests by the principles of public-private partnership, provided for the appropriate distribution of risks, responsibility and obtaining the final result, opportunities for mutually beneficial cooperation on a long-term basis. It is noteworthy that the said Law also defined the national mode of investment activity for foreign private partners, stated that the selection of a private partner is carried out on a competitive basis in the established manner

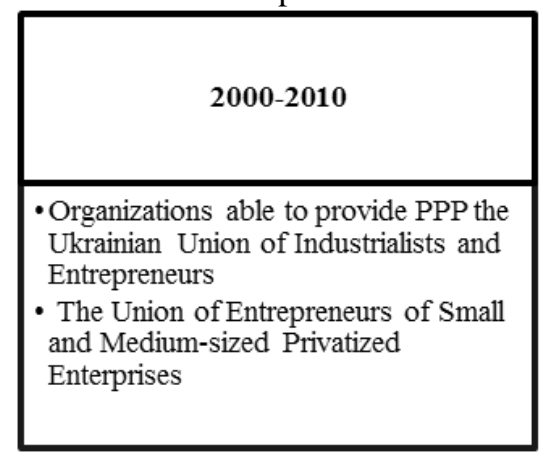

Fig. 2. Steps towards institutionalization of relations between the state and business

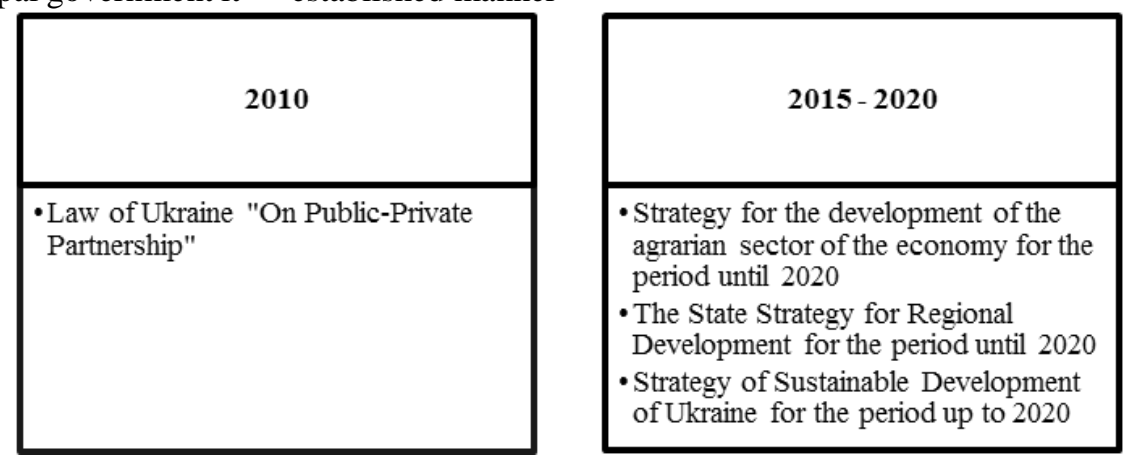

*Source:: created by the authors

European Atomic Energy Community and their Member States, on the other hand (ratified by 2014), and others. It is worth mentioning that the international practice has significantly influenced the program documents for the development of the domestic agro-industrial complex - the State target program for the development of the Ukrainian

Simultaneously a crucial role in the development of public and private partnerships in particular in agrarian sector was played by international institutional instruments, i.e. the UN Millennium Declaration and Program of Action (2000), the Okinawa Charter for a Global Information Society (2000), Council of Europe Decree No. 1698 (2005) on support for rural development, the Association Agreement between Ukraine, on the one hand, and the European Union, the

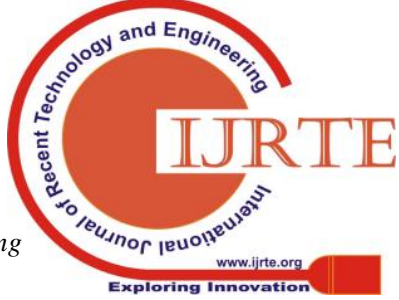


village for the period until 2015, the Strategy for the development of the agrarian sector of the economy for the period until 2020, the State Strategy for Regional Development for the period until 2020, and others. The Strategy of Sustainable Development of Ukraine for the period up to 2020 also envisages a simultaneous reform of agriculture with the synchronous introduction of the prerequisites for public-private partnership. [10]

According to the legislative norms the mechanism of public-private partnership allows choosing forms of cooperation between the public sector and agribusiness. The basic forms of such cooperation are the form of cooperation, the form of the concession, the form of the agreement, the form of leasing

The selection of the form of public-private partnership and accordingly the sources of funding and ownership affects the form of management of an agrarian enterprise. In case if the interest of agribusiness entities in interaction on the basis of the proposed form reveals, it is considered effective. Representatives of government structures should predict the degree of interest of agribusiness representatives in advance; determine the feasibility of organization of public-private partnership and the choice of its form. In year 2016 in Ukraine there were 153 concession agreements overall in all spheres and branches of economy (82,3\% of total quantity of the PPP projects), 32 agreements on cooperation and 1 project on the basis of PPP agreement. The mostly used form of the public-private agreement in Ukraine has become the concession agreement that can be defined as an agreement on the transfer of natural wealth, enterprises, other economic objects belonging to a state or a territorial community for temporary use to other states, foreign firms, individuals. [6]

In any case (using any form of PPP agreement) the government and business (including digitalization of agribusiness) remain autonomous in the implementation of public-private partnership projects. The main indicators of project efficiency for a private entrepreneur are the increase in the profitability of own funds invested in the project and the return on investment. Profitability growth is the difference between the market rate and the actual level of profitability on the own funds invested in the project. Hence, the interest in the cooperation of private capital is shaped primarily by incentives for efficiency. For the state, the combination of resources of the state sector of the economy with private resources, provided that strategic objects of state ownership are preserved. It is obviously an optimal way of implementing the priorities of state policy, solving social problems, overcoming the negative effects of crises, and modernizing the economy.

As for the digitalization of the agrarian sector of economy in our opinion there should be remembered about historical and world experience, which shows that the introduction of innovative (digital in the current conditions) changes in agriculture, as a rule, causes considerable resistance from a large part of economic operators who risk losing a privileged position or large rental income. Insufficient effectiveness of attempts to activate public-private partnership in the digitalization of agrarian sector is explained by the fact that this problem is much more fundamental, since it touches almost all objective and subjective aspects of economic activities and human being. The digital technologies penetrate firstly into business in order to reach some economic goals but they stimulate changes everywhere, including the mentality of people, raise qualitative characteristics and standards of their life, bring new social requirements.

The prospect of development of public-private partnership is always conditioned by the synchronized activity of the participants in economic relations on the principle of convergence of processes "from top to bottom" and "bottom-up", where the fundamental link in all cases is the "man-man" relationship. That is why intensification of public-private partnership in the digitalization of agrarian sector of the domestic economy requires a clear definition of the jurisdiction of each potential participant in the reform processes and the establishment of this jurisdiction at the legislative level.

The introduction of effective dialogue between government and business (including digitalization of the agribusiness) with the involvement of civil society institutions is the only way to intensify and institutionalize relations between them in the current environment. The government is a strategically oriented subject of economic development, while the business is oriented towards the realization of its own interests. That is why the government should "push" the business to actions oriented at digitalization of the agrarian sector through the creation of a set of special incentives, primarily fiscal and monetary-credit mechanisms. In addition, government actions should aim at promoting employment growth, simplifying the search, training and recruitment process for the private sector, and actively promoting social responsibility for business.

In our mind there is experience in the world that can be captured by the Ukrainian agrarian sector of economy, i.e. developing form of public-private partnership as contractual farming. It is a relatively new, progressive institutional form aimed at increasing agricultural productivity through its digitalization, especially in small farms. By engaging farmers in the block chain, contract farming provides opportunities for development from natural to commercial farming, in particular for small owners, and can provide access to loans, technologies and markets. All agribusinesses (public or private) need capital and resources. In agribusiness, contract farming virtually (thanks to the involved digital technologies) eliminates the need to purchase land as one of the most vital resources for farming. As for the state, contract farming is a potentially "win-win" solution for farmers, processors and society.

It should be noted that such a form of cooperation between the state and agro-enterprises is proposed by the world organization of the FAO, in particular, in support and development of developing countries. Private partnership is seen primarily as a means of coordinating the value chain through contract farming in order to help increase agricultural productivity and ensure food security in particular via its digitalization. For example, the application of contract farming forms is recommended for the development of poultry farming and promotion of 
aquaculture. This is due to the fact that fish and poultry have the properties to quickly spoil. In such circumstances, it is very difficult to solve the problem of the delivering the finished products by agribusiness enterprises. One of the solutions to this problem is the development of public-private partnerships, including contract farming. [7] Consequently, there are many definitions of contract farming, but in general contractual farming is essentially a form of vertical integration between producers and actors for the further development of a value chain such as agribusiness, processors, exporters or retailers. [7, p.5]

Unfortunately Ukraine still has a significant backlog in the development of public-private partnerships in particular in the digitalization of the agrarian sector. The key factors that can break the development of for instance contract farming in Ukraine are technical factors, labor complexity, specificity of assets, unacceptable pricing, availability of alternative farm income, low elasticity of incomes of producers, addicting to regular buyers, the presence of a situation where spot prices are higher than forward prices; uncertainty of ownership, lack of rule of law; lack of performance of contracts, insufficient information, corruption, cultural factors, lack of awareness of the prospects of contractual farming. To improve the situation and to create the basis for the development of public-private partnership in digitalization of the agrarian sector in Ukraine is possible through changes in the legislative and executive levels, the activation of processes of interaction between agrarian enterprises oriented at digitalization and the government, as well as agrarian enterprises among themselves, optimizing the government economic policy, reducing the risks of doing business in those sectors of the economy that require involving the digital villages.

\section{DISCUSSION}

Providing public-private partnerships oriented at digitalization of agrarian sector can become a very important step in stimulating the development of the sector and of the economy of Ukraine. Taking into consideration the importance of the sector for the economy of Ukraine both in economic and social measures and stressing on such important functions of it as providing food security, standards of animals' health, social standards, agrarian logistics, etc. it is necessary to attract attention to the problem and work out new effective ways of interaction between the state and agrarian business. Public-private partnerships can stimulate digitalization and fast modernization of the sector without direct penetration of the state into business doing. As a consequence it can stimulate the digital activity in the sector because the agrarians will try to be competitive.

However in Ukraine providing public-private partnerships oriented at digitalization of agrarian sector is not an easy task due to institutional and bureaucratic barriers, lobbying of interests of some groups frequent changes in the public policy, unprepared workers to digitalization of the sector, resistance to innovations and other negative factors. technologies and improve the quality of life of people in the

\section{CONCLUSIONS}

So that in current conditions in Ukraine it is necessary to provide new forms of cooperation between the state and private agrarian business in the direction of digitalization of it. The agrarian sector plays crucial role for the economy of Ukraine and some indices prove its primer position in it. Its development contributes a lot to the development of the whole country. Besides it bears a set of very important functions connected to both economic and social development, such as food security, agrarian products logistics to the final consumers, control over the animals' health, providing of the appropriate life level in the villages and becoming a social lift for people living there. Implementing public-private partnerships oriented at digitalization of agrarian sector can stimulate its development under the Government control on the parity basis without direct penetration of the state in agrarian business stimulating the competition in the sector. To do this it is necessary to overcome the present institutional and bureaucratic barriers in Ukraine.

Practical implications. The results of the research can be used as a source of information concerning providing public-private partnerships oriented at digitalization of agrarian sector in current conditions in Ukraine in order to stimulate the economic and social development as a whole.

\section{REFERENCES}

1. Agricultural sector of Ukraine, 2018. Securing the global food supply. Available at: file://C:/Users/User/Downloads/agro-small.pdf.

(accessed 14 September, 2019)

2. Deryabina, M. Public-private partnership: theory and practice, Voprosy ekonomiki, 8, p. 61-77, 2008.

3. Geyets, V. Society, state, economy: phenomenon of interactions and development. Institute of forecasting and development NAS of Ukraine, Kyiv, Ukraine, 2009.

4. Implementing of the projects of public-private partnership in Ukraine, 2017 Available at: https://mtu.gov.ua/files/\%D0\%9F\%D0\%BE\%D1\%81\% D1\%96\%D0\%B1\%D0\%BD\%D0\%B8\%D0\%BA\%20\% D0\%A0\%D0\%B5\%D0\%B0\%D0\%BB\%D1\%96\%D0\%B 7\%D0\%B0\%D1\%86\%D1\%96\%D1\%8F\%20\%D0\%94\% D0\%9F\%D0\%9F\%20\%D0\%B2\%20\%D0\%A3\%D0\%B A\%D1\%80\%D0\%B0\%D1\%97\%D0\%BD\%D1\%96.pdf (accessed 14 September, 2019)

5. Law of Ukraine "About Public-private partnerships" from 01.07.2010, № 2404-VI. Available at: https://zakon.rada. gov.ua/laws/show/2404-17 (accessed 24 May 2019)

6. Law of Ukraine "About concessions" from 16.07.1999, № 997-XIV. Available at: https://zakon.rada.gov.ua/ laws/show/997-14 (accessed 24 May 2019)

7. Murekezi, P., Menezes, A., Ridler, N. Contract farming and public-private partnerships in aquaculture. Lessons learned from East African countries, 2018. Available at: http://www.fao.org/3/CA0134EN/ca0134en.pdf (accessed 14 September, 2019)

8. Reznik, N., Gupta, S., Sakovska, O., Ostapchuk, A., Levkina, R. Ukrainian world exchange market of oilseeds: A research of challenges for growth. International Journal of Engineering and Advanced Technology, 8(6), p. $3823-3829,2019$. Available at:: https://www2.scopus. com/authid/detail.uri?authorId=57202444035 
9. Varnavskiy, V. Partnership of the state and private sector: forms, projects, risks. Institute of the world economy and international relations, Moscow, Russia, 2005.

10. Yushin, S. Development of public and private partnership in the agrarian sector of economy, 2015. Available at: http://www.iae.org.ua/presscentre/archnews/1263--1-r.ht $\mathrm{ml}$ (accessed 14 September, 2019) 